\title{
Prostaglandin G/H Synthase 1
}

National Cancer Institute

\section{Source}

National Cancer Institute. Prostaglandin G/H Synthase 1. NCI Thesaurus. Code C19705.

Prostaglandin G/H synthase 1 (599 aa, $\sim 69 \mathrm{kDa}$ ) is encoded by the human PT GS1 gene.

This protein plays a role in vasoconstriction, blood pressure homeostasis and prostaglandin metabolism. 